Cite this: J. Mater. Chem. A, 2013, 1, 2238

\title{
Imidazolium methanesulfonate as a high temperature proton conductort‡
}

\begin{abstract}
Jiangshui Luo, ${ }^{\text {ab }}$ Olaf Conrad ${ }^{* c}$ and Ivo F. J. Vankelecomª
Imidazolium methanesulfonate (1) has been studied as a model proton conductor for high temperature polymer electrolyte membrane fuel cells (PEMFCs). It is found that $\mathbf{1}$ undergoes transformation from crystalline to plastic crystalline and then molten states successively from ambient temperature to $200{ }^{\circ} \mathrm{C}$. The solid-solid phase transition of 1 at $174{ }^{\circ} \mathrm{C}$ has been preliminarily verified by differential scanning calorimetry (DSC) and temperature-dependent X-ray diffraction (XRD). At the melting point of $188^{\circ} \mathrm{C}, 1$ displays a low entropy of fusion of around $24 \mathrm{~J} \mathrm{~mol}^{-1} \mathrm{~K}^{-1}$. In particular, a high ionic conductivity of 1.0 $\times 10^{-2} \mathrm{~S} \mathrm{~cm}^{-1}$ is reached at $185^{\circ} \mathrm{C}$ in the plastic phase. The activation energy for ionic conduction decreases as $\mathbf{1}$ is heated from the crystal phase to the melt phase. In the molten state, the contribution of protons to the ionic conductivity of $\mathbf{1}$ was corroborated electrochemically. In addition, $\mathbf{1}$ is electrochemically active for $\mathrm{H}_{2}$ oxidation and $\mathrm{O}_{2}$ reduction at a Pt electrode while it shows a high electrochemical window of $2.0 \mathrm{~V}$. Furthermore, a Nafion ${ }^{\circledR}$ membrane has been successfully doped with 1, as identified by infrared spectroscopy, powder XRD, grazing incidence XRD and thermogravimetric analysis. To the best of our knowledge, this may be the first report on a protic organic ionic plastic crystal (OIPC) consisting of protonated imidazole $\left(\mathrm{C}_{3} \mathrm{H}_{5} \mathrm{~N}_{2}{ }^{+}\right)$and an organic anion. The good thermal stability, high ionic conductivity, wide electrochemical window, favorable plastic crystal behavior and simple synthesis make $\mathbf{1}$ a highly interesting model proton conductor for high temperature PEMFCs.
\end{abstract}

Received 15th October 2012 Accepted 5th December 2012

DOI: $10.1039 / \mathrm{c} 2 \mathrm{ta00713d}$

www.rsc.org/MaterialsA melting, which is typically less than $20 \mathrm{~J} \mathrm{~mol}^{-1} \mathrm{~K}^{-1}$ according to Timmermans' criterion for a plastic crystal, ${ }^{7}$ and one or more solid-solid phase transitions, they are regarded as protic OIPCs, even though their melting points may be lower than $100{ }^{\circ} \mathrm{C} .{ }^{8}$

PILs, which are formed by proton transfer from a Brønsted acid to a Brønsted base, have been intensively explored as promising non-aqueous electrolytes for high temperature $\left(100-200{ }^{\circ} \mathrm{C}\right)$ polymer electrolyte membrane fuel cells (PEMFCs), due to their merits of high proton conductivity, good thermal and electrochemical stability, low vapor pressure, non-flammability, and ease of synthesis. ${ }^{9-19}$ For example, Watanabe et al. ${ }^{11}$ recently demonstrated that a nonhumidified PEMFC using sulfonated polyimide/ diethylmethylammonium triflate composite membranes could be operated at a maximum power density of $100 \mathrm{~mW} \mathrm{~cm}^{-2}$ at $120{ }^{\circ} \mathrm{C}$ without humidification. However, the long-term operation of the PIL-based membranes may be affected by a progressive release of the PIL component, leading to the decline of fuel cell performance. ${ }^{12,13}$

OIPCs are crystalline phases found in the organic salt families that exhibit various forms of disorder and therefore exhibit plastic mechanical properties., ${ }^{2,8}$ As unique electrolyte materials, they offer important properties such as intrinsic ionic conductivity, non-flammability, negligible vapor pressure, plasticity and high electrochemical and thermal stability, while eliminating the leakage problems associated with liquid electrolytes. ${ }^{2}$ Particularly, their plasticity is highly advantageous for 
their applications in electrochemical devices as it can improve the contact between the electrolyte and the electrodes for the fabrication of electrochemical devices or against possible volume changes after fabrication. Hence, OIPCs have been attracting increasing interest in the fields of lithium batteries, solar cells and fuel cells., ${ }^{2,8,19-25}$

Previously reported proton-conducting plastic crystals as electrolytes for PEMFCs were often doped plastic crystals, which used acids, PILs or bases as the dopants for doping the matrix of a certain neat plastic crystal (e.g. succinonitrile and choline triflate). ${ }^{26-29}$ Recently, a new class of proton-conducting OIPCs utilizing the dihydrogenphosphate anion, which can generate protons as a carrier and in fact correspond to Brønsted acidic ionic liquids, ${ }^{4}$ has been reported. ${ }^{30,31}$ In addition, Horike et al. ${ }^{25}$ reported a protic OIPC consisting of protonated imidazole $\left(\mathrm{C}_{3} \mathrm{H}_{5} \mathrm{~N}_{2}^{+}\right)$and anionic one-dimensional chains of $\mathrm{Zn}^{2+}$ phosphate. The $\mathrm{Zn}$ coordination networks in $\left[\mathrm{Zn}\left(\mathrm{HPO}_{4}\right)\left(\mathrm{H}_{2}-\right.\right.$ $\left.\left.\mathrm{PO}_{4}\right)_{2}\right]\left(\mathrm{C}_{3} \mathrm{H}_{5} \mathrm{~N}_{2}\right)_{2}$ were found to provide a delocalized anionic backbone for gentle entrapment of $\mathrm{C}_{3} \mathrm{H}_{5} \mathrm{~N}_{2}{ }^{+}$to produce a high proton conductivity of $2.6 \times 10^{-4} \mathrm{~S} \mathrm{~cm}^{-1}$ at $130{ }^{\circ} \mathrm{C}$ in the plastic phase without humidity. ${ }^{25}$ Nevertheless, there are still very limited reports on protic OIPCs, ${ }^{19,25,32-35}$ which have intrinsic proton conductivity and are pure plastic crystals, obviating the need for the addition of a dopant that may be incompatible with the host matrix. ${ }^{27}$

Herein, we present our recent work on imidazolium methanesulfonate as a model proton conductor, prepared from imidazole $\left(\mathrm{p} K_{\mathrm{a} 1}=6.99, \mathrm{p} K_{\mathrm{a} 2}=14.44\right){ }^{36}$ which is a moderately strong base and has been intensively studied as a proton conductor, ${ }^{37,38}$ and $\mathrm{CH}_{3} \mathrm{SO}_{3} \mathrm{H}$, which is a strong Brønsted acid $\left(\mathrm{p} K_{\mathrm{a} 1}=-1.92\right)^{39}$ and mimics the sulfonic acid moiety of Nafion ${ }^{\circledR}$. The thermal, structural and interfacial electrochemical properties as well as ionic conductivity of imidazolium methanesulfonate have been investigated in detail. The presence of a plastic crystal phase shortly before the melting point was observed. Furthermore, a composite membrane prepared from 1 using Nafion ${ }^{\circledR}$ as a host matrix has been initially characterized.

\section{Experimental}

\subsection{Chemicals}

Imidazolium methanesulfonate $\left(\mathrm{C}_{3} \mathrm{H}_{5} \mathrm{~N}_{2}{ }^{+} \cdot \mathrm{CH}_{3} \mathrm{SO}_{3}{ }^{-}\right.$(1)) was synthesized by mixing equimolar amounts of imidazole $\left(\mathrm{C}_{3} \mathrm{H}_{4} \mathrm{~N}_{2}\right.$, Sigma-Aldrich, $\left.\geq 99.5 \%\right)$ and methanesulfonic acid $\left(\mathrm{CH}_{3} \mathrm{SO}_{3} \mathrm{H}\right.$, Sigma-Aldrich, $\left.\geq 99.5 \%\right)$ in a UniLab glove box (MBRAUN) under pure $\mathrm{N}_{2}$ atmosphere (water content $<0.1 \mathrm{ppm}$ ) and then heating the mixture above the melting point to promote the formation of the protic salt. ${ }^{40}$ The samples were stored in the glove box. Prior to the synthesis, the water contents of imidazole and methanesulfonic acid were determined by coulometric Karl Fischer titration to be less than 1000 ppm and $2700 \mathrm{ppm}$, respectively, while no halide ions were detected in $\mathbf{1}$ determined from ion chromatographic analysis. ${ }^{\mathbf{4 0}}$

In addition, an imidazole solution of 1 was prepared from the combination of $\mathrm{C}_{3} \mathrm{H}_{4} \mathrm{~N}_{2}$ and $\mathrm{CH}_{3} \mathrm{SO}_{3} \mathrm{H}$ with a molar ratio of $n\left(\mathrm{C}_{3} \mathrm{H}_{4} \mathrm{~N}_{2}\right) / n\left(\mathrm{CH}_{3} \mathrm{SO}_{3} \mathrm{H}\right)=85 / 15$ in the same glove box. The solution, with a melting point below $65{ }^{\circ} \mathrm{C}$, was heated to liquid state and stirred for several hours. Meanwhile, Nafion ${ }^{\circledR} 212$ membranes were dried in a vacuum oven (ultimate pressure: 2 $\times 10^{-3}$ mbar) at $90{ }^{\circ} \mathrm{C}$ for about $12 \mathrm{~h}$. Composite membranes were prepared by soaking the pristine Nafion 212 membranes in the imidazole solution of $\mathbf{1}$ at $80{ }^{\circ} \mathrm{C}$ for about 2 days. The membranes were taken out and carefully dabbed with filter paper to remove excess solution on the surface. Finally, they were heated in a vacuum oven at $60{ }^{\circ} \mathrm{C}$ overnight to remove excess imidazole. The doping level of $\mathbf{1}$ was calculated to be around $30 \%$ by comparing the increased weight of membranes after doping and drying $v s$. the weight of pristine membranes before doping.

\subsection{X-ray diffraction (XRD) studies}

Temperature-dependent powder XRD patterns of $\mathbf{1}$ in an $\mathrm{Ar}$ atmosphere were recorded on a powder X-ray diffractometer (X'Pert PRO, PANalytical) using $\mathrm{Cu} \mathrm{K} \alpha$ radiation $(\lambda=1.5406 \AA)$ at $25{ }^{\circ} \mathrm{C}$ and then from $165{ }^{\circ} \mathrm{C}$ to $191^{\circ} \mathrm{C}$ at $1 \mathrm{~K}$ interval to identify solid-solid phase transition. The sample was placed on a clean, dry and flat glass plate in an Anton Paar HTK $1200 \mathrm{~N}$ ovenchamber and stabilized at each temperature (accuracy: $\pm 1{ }^{\circ} \mathrm{C}$ ) for about $20 \mathrm{~min}\left(30 \mathrm{~min}\right.$ for $165^{\circ} \mathrm{C}$ ) before each measurement. The temperature ramp between two consecutive temperatures was $5 \mathrm{~K} \mathrm{~min}^{-1}$. Each measurement consisted of a $\theta-2 \theta$ scan from $10^{\circ}$ to $50^{\circ}$, a step size of $0.052^{\circ}$ and a total time per scan of $16 \mathrm{~min}$.

Structural analysis of the membranes was carried out with the above X-ray diffractometer by grazing incidence X-ray diffraction (GIXRD), using $\mathrm{Cu} \mathrm{K} \alpha$ radiation at an incident angle $(\omega)$ of $0.5^{\circ}$ to the specimen surface. Each measurement consisted of a $2 \theta$ scan from $2^{\circ}$ to $50^{\circ}$ and a step size of $0.015^{\circ}$. Additionally, powder XRD patterns of the membranes were collected on the same X-ray diffractometer with a $\theta-2 \theta$ scan from $5^{\circ}$ to $50^{\circ}$, a step size of $0.013^{\circ}$ and a total time per scan of 15 min.

\subsection{Thermal analysis}

Thermogravimetric analysis (TGA) for $\mathbf{1}$ was carried out on a thermogravimetry/differential thermal analyzer (TGA/SDTA $851^{\mathrm{e}}$, Mettler Toledo) from room temperature to $500{ }^{\circ} \mathrm{C}$ at a heating rate of $10 \mathrm{~K} \mathrm{~min}^{-1}$ and under a $\mathrm{N}_{2}$ flow of $60 \mathrm{~mL} \mathrm{~min}^{-1}$ with covered $\mathrm{Al}_{2} \mathrm{O}_{3}$ pans. The sample weight was around $12 \mathrm{mg}$. The onset temperature for the mass loss process during the heating scan was used as the decomposition temperature $\left(T_{\mathrm{d}}\right)$.

TGA for the membranes was recorded on a thermogravimetric analyzer (TGA 4000, PerkinElmer) in a stream of $\mathrm{N}_{2}(100$ $\mathrm{mL} \mathrm{min}^{-1}$ ) with an open $\mathrm{Al}_{2} \mathrm{O}_{3}$ pan. The temperature range was from 30 to $800{ }^{\circ} \mathrm{C}$ with a heating rate of $10 \mathrm{~K} \mathrm{~min}^{-1}$. Each sample weight was about $13 \mathrm{mg}$.

Differential scanning calorimetry (DSC) measurements for 1 of approximately $11 \mathrm{mg}$ were conducted with a Netzsch DSC 204 F1 Phoenix instrument under a $\mathrm{N}_{2}$ atmosphere. The samples, tightly sealed in aluminum pans, were first heated from $30^{\circ} \mathrm{C}$ to $250{ }^{\circ} \mathrm{C}$ and then cooled to $-20{ }^{\circ} \mathrm{C}$ and subsequently heated to $250{ }^{\circ} \mathrm{C}$ again at a rate of $5 \mathrm{~K} \mathrm{~min}^{-1}$. DSC thermograms were 
recorded during the reheating scans. Solid-solid phase transition temperature $\left(T_{\text {solid-solid }}\right)$ and melting point $\left(T_{\mathrm{m}}\right)$ of 1 were determined from onset temperatures of the related phase transitions in the DSC thermograms. The entropy of fusion $\left(\Delta S_{\mathrm{f}}\right)$ was calculated from the melting endotherm area $\left(\Delta H_{\mathrm{f}}\right)$ according to $\Delta S_{\mathrm{f}}=\Delta H_{\mathrm{f}} / T_{\mathrm{m}}{ }^{8}$

\section{4 pH titration}

The $\mathrm{pH}$ value of the aqueous solution of $\mathbf{1}$ with a mass fraction of $0.10 \%$ was determined by $\mathrm{pH}$ titrations using a TitroLine alpha plus (SI Analytics).

\subsection{Fourier transform infrared (FT-IR) spectra}

FT-IR spectra of the membranes and imidazole were recorded at room temperature on a PerkinElmer Spectrum 100 FT-IR spectrometer with universal ATR accessory at a spectral resolution of $4 \mathrm{~cm}^{-1}$.

\subsection{Ionic conductivity}

The ionic conductivity of $\mathbf{1}$ in the solid state near the melting point was estimated by complex impedance spectroscopy using a platinized conductivity cell (model 6.0908.110, Metrohm) and a Solartron 1255B Frequency Response Analyzer combined with a Solartron 1287 Electrochemical Interface. Firstly, a diptype glass cell containing 1 was heated at $190{ }^{\circ} \mathrm{C}$ in a silicon oil bath (accuracy: $\pm 1{ }^{\circ} \mathrm{C}$ ) to let $\mathbf{1}$ stay in the liquid state, and then the dry and preheated conductivity cell was immersed into melted 1. Subsequently, the sample was cooled down to $180{ }^{\circ} \mathrm{C}$ slowly. The impedance was measured in the frequency range from $1 \mathrm{~Hz}$ to $1 \mathrm{MHz}$. Then the sample was heated to $185^{\circ} \mathrm{C}$ to obtain the corresponding impedance. The sample was thermally equilibrated at each temperature for at least 40 min prior to each measurement. Later, the cell constant was calibrated with $0.01 \mathrm{~mol} \mathrm{~L}^{-1} \mathrm{KCl}$ solution at $25{ }^{\circ} \mathrm{C}$ and found to be almost the same as the value prior to the conductivity test, implying the feasibility of the measurement method. Other test details can be referred to our previous work. ${ }^{41}$

\subsection{Electrochemical polarization}

The interfacial electrochemical properties of $\mathbf{1}$ in the melt state were investigated at $210{ }^{\circ} \mathrm{C}$ by employing a three-electrode system with a $1 \mathrm{~mm}$ diameter Pt wire (Radiometer Analytical), an $8 \mathrm{~mm} \times 8 \mathrm{~mm}$ Pt plate (Radiometer Analytical) and a $10 \mathrm{~mm}$ diameter Pt disk (Radiometer Analytical) as the working electrode (WE), the counter electrode (CE) and the reference electrode (RE), respectively (Fig. S1). $\neq$ The RE was immersed in $\mathbf{1}$ with continuous $\mathrm{H}_{2}$ bubbling as a reversible hydrogen electrode (RHE) and placed close to the WE through a Luggin capillary. ${ }^{9}$ The system was connected to a Solartron 1287 Electrochemical Interface linked to a computer and monitored by the CorrWare ${ }^{\circledR}$ (Scribner Associates) software. The temperature was regulated in the silicon oil bath (accuracy: $\pm 1{ }^{\circ} \mathrm{C}$ ). Chronoamperometric, cyclic voltammetric and linear sweep voltammetric measurements for $\mathbf{1}$ are similar to what has been described previously. ${ }^{40}$
Chronoamperograms were obtained with the WE under dry $\mathrm{N}_{2}$ or $\mathrm{H}_{2}$ gas bubbling atmosphere to confirm the contribution of protons to the ionic conductivity. The $\mathrm{H}_{2}$ flow rate for the $\mathrm{WE}$ was about $3 \mathrm{~mL} \mathrm{~min}^{-1}$. A constant DC voltage of $500 \mathrm{mV}$ was applied on the WE vs. open circuit potential for chronoamperometric measurements.

Cyclic voltammograms were recorded at a scan rate of $20 \mathrm{mV} \mathrm{s}^{-1}$ with the WE under dry $\mathrm{N}_{2}, \mathrm{H}_{2}$, or $\mathrm{O}_{2}$ gas bubbling atmosphere, respectively. $\mathrm{H}_{2}$ and $\mathrm{O}_{2}$ flow rates were both about $3 \mathrm{~mL} \mathrm{~min}^{-1}$. The potential of the WE was scanned from the open circuit potential (OCP) to $-0.025 \mathrm{~V}$ for the first scan followed by scanning to $+1.2 \mathrm{~V}$ and finally to the OCP.

Electrochemical stability was analyzed with linear sweep voltammetry recorded at $10 \mathrm{mV} \mathrm{s}^{-1}$ with the WE in dry $\mathrm{N}_{2}$ sparged electrolyte.

\section{Results and discussion}

\subsection{Thermal and structural analysis}

Fig. 1 presents the TGA trace of 1 in a $\mathbf{N}_{2}$ atmosphere at a heating rate of $10 \mathrm{~K} \mathrm{~min}^{-1}$. It shows that 1 has a relatively high thermal stability with a one-step weight loss process and a $T_{\mathrm{d}}=$ $375^{\circ} \mathrm{C}$. Infrared analysis confirmed the completeness of the salt formation of $1 .^{40}$ Obviously, imidazolium methanesulfonate was formed at the equimolar composition according to the following equation:

$$
\mathrm{C}_{3} \mathrm{H}_{4} \mathrm{~N}_{2}+\mathrm{CH}_{3} \mathrm{SO}_{3} \mathrm{H} \rightarrow \mathbf{1}
$$

In addition, the $\mathrm{pH}$ value of the aqueous solution of 1 with a mass fraction of $0.100 \%$ was found to be 4.80 , indicating that $\mathrm{C}_{3} \mathrm{H}_{5} \mathrm{~N}_{2}{ }^{+}$is a very weak acid and consequently $\mathbf{1}$ has a high degree of ionization ( $\sim 99.8 \%)$ in aqueous solution. $\neq$

As displayed in Fig. 2, the DSC trace of 1 heated at $5 \mathrm{~K} \mathrm{~min}^{-1}$ shows evidence of two phase transitions over the temperature range studied with the highest temperature solid phase denoted by phase I and subsequent lower temperature phase denoted by phase II, following the phase nomenclature method described by Chezeau and Strange. ${ }^{42}$ No thermal transition peaks were observed between -100 and $50{ }^{\circ} \mathrm{C}$ (Fig. S2). $\neq$

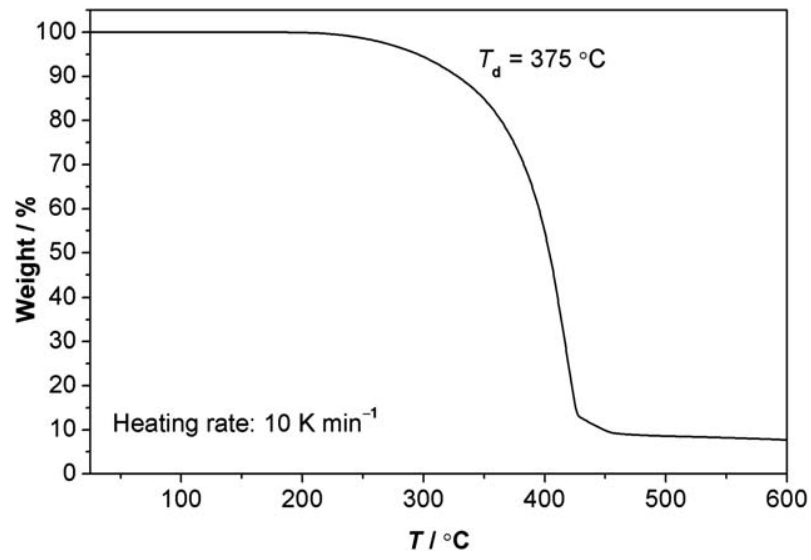

Fig. 1 TGA trace of 1 in a $\mathrm{N}_{2}$ atmosphere heated at $10 \mathrm{~K} \mathrm{~min}^{-1}$ 


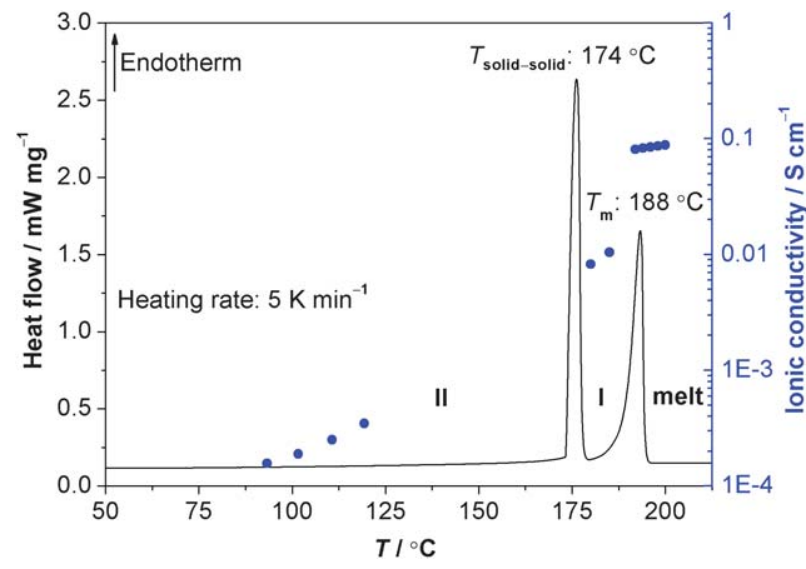

Fig. 2 DSC trace (second heating cycle) of 1 heated at $5 \mathrm{~K} \mathrm{~min}^{-1}$ and the ionic conductivity as a function of temperature. The onset temperatures for each phase transition are given. The solid circles represent the ionic conductivity, wherein the data for the melt and phase II are cited from ref. 40 and 44, respectively.

The phase II $\rightarrow$ I endothermic transition is confirmed by temperature-dependent powder XRD to be a solid-solid phase transition, as discussed later. Accordingly, $T_{\text {solid-solid }}$ is determined to be about $174{ }^{\circ} \mathrm{C}$ and the corresponding entropy change is $29 \mathrm{~J} \mathrm{~mol}^{-1} \mathrm{~K}^{-1}$. Goward et al. identified the ring reorientation of 1 using solid state NMR spectroscopy and that the imidazolium cation rotates around its $C_{2}$ axis. ${ }^{43}$ The process was found to occur at temperatures between 240 and $380 \mathrm{~K}$, which lies in phase II here, and was described by a single activation energy of $38 \pm 5 \mathrm{~kJ} \mathrm{~mol}^{-1}$. This value correlates well with the activation energy of $36.3 \pm 3.2 \mathrm{~mol}^{-1}$ for the ionic conduction of 1 in phase II (Table 1), which is calculated herein from the temperature dependence of ionic conductivity between 366 and $393 \mathrm{~K}$ measured by impedance spectroscopy. ${ }^{44}$ In addition, the ionic conductivity of imidazolium methylphosphonate obtained with impedance spectroscopy from room temperature to $388 \mathrm{~K}$ showed an activation energy of $42 \pm 2 \mathrm{~kJ} \mathrm{~mol}^{-1}$. $^{45}$ The reasonable correlation among these activation energies is additional evidence that the imidazolium ring reorientation process may be the rate-determining step in proton transport in imidazole-based proton conducting materials, likely described by a Grotthuss mechanism (structural diffusion). ${ }^{25,43,46}$ Furthermore, the concave Arrhenius plot of the temperature dependence of ionic conductivity ${ }^{\mathbf{4 4}}$ between 366 and $393 \mathrm{~K}$ may be due to the fact that increasing temperature introduces thermal motion and promotes the rotation of the imidazole ring. Indeed, while the ionic conductivity of 1 exceeds $1 \times 10^{-4} \mathrm{~S} \mathrm{~cm}^{-1}$ from $363 \mathrm{~K}$ upwards, ${ }^{44}$ increased mobility of the imidazole ring was observed for 1 and imidazolium methylphosphonate at $360 \mathrm{~K}$ or above 364 $\mathrm{K}$, respectively, using solid-state NMR. ${ }^{45}$ Additionally, Horike

Table 1 Activation energy, $E_{\mathrm{a}}$, for ionic conduction in each phase

\begin{tabular}{lccc}
\hline Phase & II & I $^{a}$ & Melt \\
\hline$E_{\mathrm{a}} / \mathrm{kJ} \mathrm{mol}^{-1}$ & $36.3 \pm 3.2$ & - & $20.3 \pm 0.13$ \\
${ }^{a}$ Insufficient data for phase I. & &
\end{tabular}

et $a .^{25}$ observed an acceleration of motion of the imidazolium cation in the ionic coordination network consisting of the imidazolium cation and anionic one-dimensional chains of $\mathrm{Zn}^{2+}$ phosphate at around $343 \mathrm{~K}$, leading to the nonlinear increase of the conductivity.

Goward et al. also demonstrated the tetrahedral reorientation of the methylphosphonate anion in imidazolium methylphosphonate at room temperature. ${ }^{45,47}$ The methylphosphonate ion is structurally analogous to the methanesulfonate anion in $\mathbf{1}$. The structural similarity of the two salts suggests that the tetrahedral reorientation is likely present in the methanesulfonate anion even in phase II. Therefore, we suggest that the $\mathrm{CH}_{3} \mathrm{SO}_{3}{ }^{-}$anion begins tumbling in phase II, which may also explain the relatively high ionic conductivity of 1 in phase II shown in Fig. 2.

As shown in Fig. 2, for the phase $\mathrm{I} \rightarrow$ melt transition, $T_{\mathrm{m}}$ is obtained to be around $188^{\circ} \mathrm{C}$, which is consistent with previous DSC measurement results recorded at $10 \mathrm{~K} \mathrm{~min}^{-1}$. $^{40}$ This melting transition was also visually confirmed by heating samples of 1 slowly from $165^{\circ} \mathrm{C}$ to $190{ }^{\circ} \mathrm{C}$ at $1 \mathrm{~K}$ intervals $( \pm 0.01$ $\mathrm{K})$ in a temperature-regulated silicon oil bath. $\Delta S_{\mathrm{f}}$ is calculated to be $24 \mathrm{~J} \mathrm{~mol}^{-1} \mathrm{~K}^{-1}$, just slightly outside Timmermans' criterion for a plastic crystal. Pringle et al..$^{2,8}$ pointed out that for an OIPC, which contains two different ions, $\Delta S_{\mathrm{f}}$ may be higher than $20 \mathrm{~J} \mathrm{~mol}^{-1} \mathrm{~K}^{-1}$, as is observed for a number of OIPCs, including some aprotic pyrrolidinium, ammonium, pyrazolium and phosphonium salts. ${ }^{\mathbf{8} 48-51}$ Hence, phase I, ranging from 174 to $188^{\circ} \mathrm{C}$, may be regarded as the plastic phase of 1 and is expected to display a high ionic conductivity correspondingly.

According to Goward et al., ${ }^{\mathbf{4 3}}$ at lower temperatures, 1 crystallizes in the orthorhombic space group, $\mathrm{Pbca}$, with cell parameters of $a=7.918 \AA, b=11.040 \AA$, and $c=16.086 \AA$. The experimental XRD pattern of 1 at 25 and $165{ }^{\circ} \mathrm{C}$ agrees well with the calculated powder XRD pattern (not shown here), confirming that 1 has an orthorhombic lattice below $166^{\circ} \mathrm{C}$. While phase transitions are commonly found in molecular crystals, and are often associated with a sudden change in (reorientational) molecular motion as well as a change in crystal structure $^{\mathbf{4 2}}$ there are few reports in the literature that detail the changes in crystal structures for OIPCs. Changes in crystal symmetry have been observed by temperature-dependent powder XRD for only a few OIPCs..$^{35,50-54}$ Generally, the high temperature plastic phase has high lattice symmetry such as described by cubic or hexagonal space groups. ${ }^{35,42,51-53}$ For example, tetraethylphosphonium fluorohydrogenate salt, $\mathrm{P}_{2222}(\mathrm{FH})_{2} \mathrm{~F}$, has been found to have a hexagonal lattice in phase I (the high temperature phase) and an orthorhombic lattice in phase II. ${ }^{53}$ In particular, as a protic OIPC, trimethylammonium trifluoroacetate has been reported to have cubic and tetragonal crystal structures in phase I and II, respectively, exhibiting higher symmetry in higher temperature phases. ${ }^{35}$

Similarly, as shown in Fig. 3, the powder XRD patterns of 1 in an Ar atmosphere as a function of temperature clearly demonstrate that 1 experiences structural changes with increasing temperature. From 25 to $165{ }^{\circ} \mathrm{C}$, the powder XRD pattern shows all reflections of the orthorhombic space group undergoing a slight shift in their $2 \theta$ values resulting from 


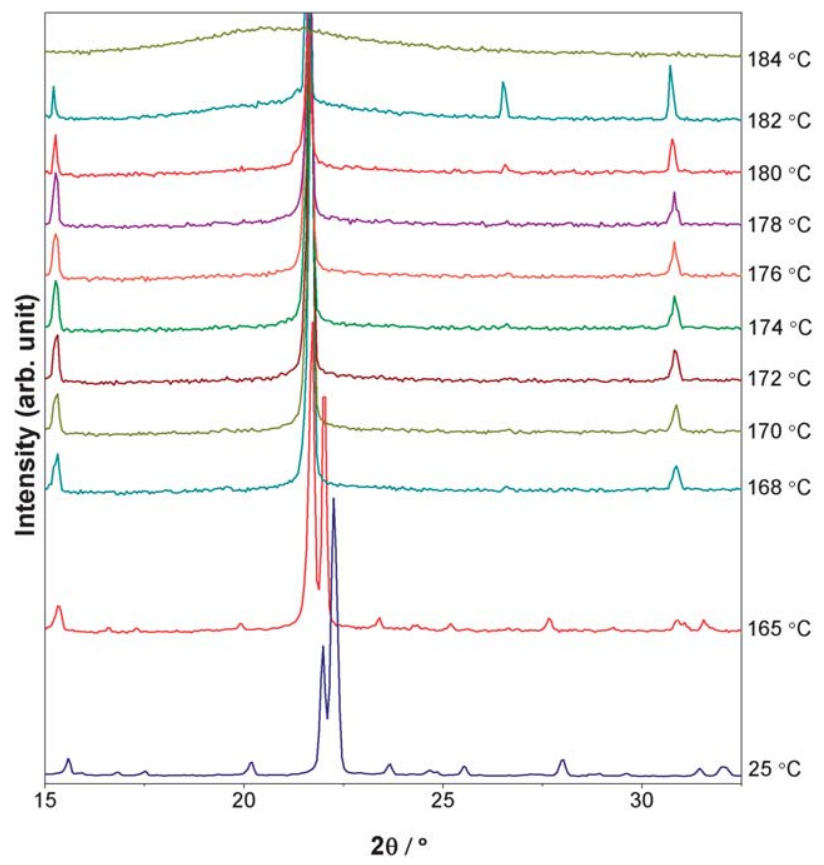

Fig. 3 Powder XRD patterns of $\mathbf{1}$ in an Ar atmosphere as a function of temperature.

temperature-induced lattice expansion. From 165 to $168{ }^{\circ} \mathrm{C}$, some reflections disappear (Fig. S3), $\neq$ implying an increase in space group symmetry. The temperature for this transition is in excellent agreement with the endothermic effect in the DSC experiment for the transition of phase II $\rightarrow$ phase I shown in Fig. 2. The difference in onset temperatures of lattice transformation and thermal transition should be due to the different heating methods for powder XRD and DSC measurements. From 168 to $178^{\circ} \mathrm{C}$, the powder XRD patterns do not change. From 180 to $184^{\circ} \mathrm{C}$, the diffraction peaks begin to diminish and finally vanish at $184^{\circ} \mathrm{C}$ somewhat ahead of the melting point at $188^{\circ} \mathrm{C}$. This is analogous to what we observed for 1,2,4-triazolium methanesulfonate, whose crystallinity was lost at around $129^{\circ} \mathrm{C}$ prior to its melting point of $134^{\circ} \mathrm{C} .{ }^{41}$ Importantly, visual observation confirms that 1 is still solid at $185^{\circ} \mathrm{C}$, validating that phase I ranges from 174 to $188^{\circ} \mathrm{C}$. It is also noted that the weak diffraction peak at around $2 \theta=26.5^{\circ}$ becomes stronger in the temperature range of $180-183^{\circ} \mathrm{C}$ (Fig. S3). $\neq$ This probably arises from some randomly oriented or heavily disordered cations. ${ }^{25,51}$ Although the detailed structural changes at higher temperatures have not been deduced, the solid-solid phase transition of $\mathbf{1}$ at around $174{ }^{\circ} \mathrm{C}$ depicted in Fig. 2 has been preliminarily confirmed by the temperature-dependent powder XRD patterns of $\mathbf{1}$. The loss of diffraction peaks is consistent with an increase in lattice symmetry for the high temperature plastic phase, ${ }^{35,42,51-53}$ indicating the presence of dynamic rotational disorder which leads to the plastic properties.

\subsection{Ionic conductivity}

The temperature dependence of the ionic conductivity of $\mathbf{1}$ is also shown in Fig. 2, wherein the data for the melt and phase II are cited from our previous work ${ }^{40}$ and Chang et al. ${ }^{44}$ respectively. The ionic conductivity increases with raising temperature and exhibits changes in slopes at the phase transitions. Its rapid increase in phase II indicates its larger temperature dependence and may be partly ascribed to the increasing rotational disorder of the imidazolium cation in the relevant temperature range as observed before. ${ }^{25,45} \mathrm{In}$ addition, it jumps at $188{ }^{\circ} \mathrm{C}$ corresponding to the phase $\mathrm{I} \rightarrow$ melt transition and then rises steadily in the melt state up to $8.85 \times 10^{-2} \mathrm{~S} \mathrm{~cm}^{-1}$ at $200{ }^{\circ} \mathrm{C}$. Particularly, a liquid-like ionic conductivity of $1.0 \times 10^{-2} \mathrm{~S}$ $\mathrm{cm}^{-1}$ is reached at $185^{\circ} \mathrm{C}$, again indicating the high disorder of 1 in phase I. One possible explanation for higher ionic conductivity in more disordered phases may be that the disordering or rotational motion creates vacancies, facilitating the motion of ions. ${ }^{55}$

It has been discovered that organic molecular ions such as imidazolium cations and tetrabutylammonium cations can diffuse in the plastic crystals. ${ }^{48,51}$ Very recently, Pringle et al. ${ }^{56}$ discovered that both the cation and the anion of $\left[\mathrm{P}_{1,2,2,4}\right]\left[\mathrm{PF}_{6}\right]$, an OIPC, can diffuse in its plastic phase. As 1 lost its crystallinity at $184{ }^{\circ} \mathrm{C}$, it is speculated that imidazolium cations and methanesulfonate anions diffuse in phase I. In this case, the vehicle mechanism ${ }^{57}$ for proton conduction is assumed to function for proton conduction in phase I, leading to a high ionic conductivity as observed. Actually, the proton conductivity of protonated imidazole based solid materials (e.g. imidazolium methylphosphonate) at ambient temperature has been demonstrated earlier. ${ }^{45,58}$ Furthermore, a vehicle mechanism has been postulated to govern the proton conduction for $\mathbf{1}$ in the molten state with the imidazolium cation as a vehicle. ${ }^{40}$

The activation energy $\left(E_{\mathrm{a}}\right)$ for each phase was calculated using the following Arrhenius equation:

$$
\sigma=\sigma_{0} \exp \left(\frac{-E_{\mathrm{a}}}{R T}\right)
$$

where $\sigma$ is the ionic conductivity, $\sigma_{0}$ the pre-exponential factor, $E_{\mathrm{a}}$ the activation energy, $R$ the universal gas constant, and $T$ the absolute temperature. The values are listed in Table 1 . They are relatively small as compared to activation energies of other OIPCs. ${ }^{25,50,51,55}$ On the whole, $E_{\mathrm{a}}$ decreases as $\mathbf{1}$ is heated through each phase transition, which is in line with the same trend observed in some aprotic OIPCs ${ }^{50,51,56}$ and reflects the phasedependent transport properties of $\mathbf{1}$. Obviously, the greater $E_{\mathrm{a}}$ in phase II means ionic conduction in $\mathbf{1}$ needs more energy at lower temperatures.

\subsection{Interfacial electrochemical properties}

As the melting point of $\mathbf{1}$ is as high as $188^{\circ} \mathrm{C}$, the characterizations of interfacial electrochemical properties of $\mathbf{1}$ as a protic molten salt were performed at $210{ }^{\circ} \mathrm{C}$. Fig. $4 \mathrm{a}$ presents chronoamperograms for 1 under $\mathrm{H}_{2}$ and $\mathrm{N}_{2}$ atmosphere, respectively, with an applied DC voltage of $500 \mathrm{mV}$ on the WE. The current measured under the $\mathrm{N}_{2}$ atmosphere quickly attenuated to nearly zero within a few seconds and stabilized at around $8 \mu \mathrm{A} \mathrm{cm} \mathrm{cm}^{-2}$, indicating the formation of an electric double layer. ${ }^{59-62}$ In contrast, a significant and relatively stable current, 

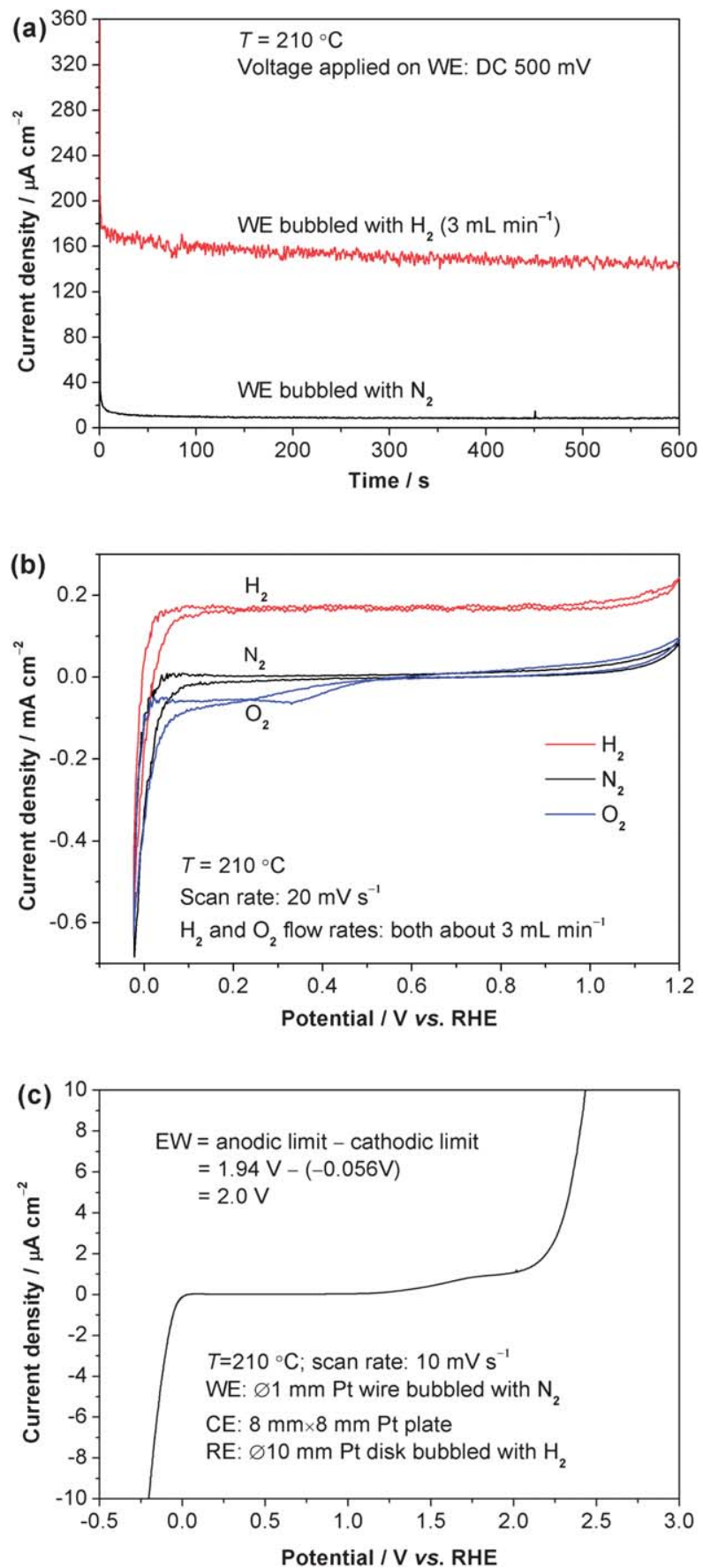

Fig. 4 (a) Chronoamperograms for 1 under $\mathrm{H}_{2}$ or $\mathrm{N}_{2}$ atmosphere at $210{ }^{\circ} \mathrm{C}$ with an applied DC voltage of $500 \mathrm{mV}$ on the WE, (b) cyclic voltammograms for 1 under $\mathrm{H}_{2}, \mathrm{~N}_{2}$ or $\mathrm{O}_{2}$ atmosphere, and (c) linear sweep voltammogram for $\mathbf{1}$ under a $\mathrm{N}_{2}$ atmosphere.

which should be attributed to the hydrogen oxidation reaction (HOR) at the WE, was observed under $\mathrm{a}_{2}$ atmosphere, indicating the contribution of protons to the ionic conductivity of 1. Obviously, the acceptor of the proton generated herein by the HOR is either $\mathrm{CH}_{3} \mathrm{SO}_{3}{ }^{-}$anions or imidazole molecules. At the very beginning of the chronoamperometric test, protons generated by the $\mathrm{HOR}$ at the WE are accepted by $\mathrm{CH}_{3} \mathrm{SO}_{3}{ }^{-}$ anions, resembling the HOR in diethylmethylammonium trifluoromethanesulfonate. ${ }^{9}$ That is because there is almost no free imidazole due to the large equilibrium constant of the proton transfer reaction indicated by the high thermal stability of 1 reported here, the completeness of the salt formation ${ }^{\mathbf{4 0}}$ for $\mathbf{1}$ and the prominent difference between $\mathrm{p} K_{\mathrm{a}}$ values of imidazole and $\mathrm{CH}_{3} \mathrm{SO}_{3} \mathrm{H}\left(\Delta \mathrm{p} K_{\mathrm{a}} \approx 9\right) .{ }^{6,17}$ The initial anodic reaction is likely:

$$
\text { Anode (WE): } \mathrm{H}_{2}+2 \mathrm{CH}_{3} \mathrm{SO}_{3}{ }^{-} \rightarrow 2 \mathrm{CH}_{3} \mathrm{SO}_{3} \mathrm{H}+2 \mathrm{e}^{-}
$$

Meanwhile, imidazole is generated at the CE:

$$
\text { Cathode (CE): } 2 \mathrm{C}_{3} \mathrm{H}_{5} \mathrm{~N}_{2}^{+}+2 \mathrm{e}^{-} \rightarrow 2 \mathrm{C}_{3} \mathrm{H}_{4} \mathrm{~N}_{2}+\mathrm{H}_{2}
$$

However, $\mathrm{CH}_{3} \mathrm{SO}_{3}{ }^{-}$anion is a much weaker base than imidazole. As shown in Scheme 1, when imidazole is generated at the $\mathrm{CE}$, it is likely that imidazole would subsequently play the role of a proton acceptor by the fast proton hopping mechanism: (i) between imidazolium cation (protonated imidazole) and imidazole near the cathode-electrolyte interface and in the electrolyte bulk; and (ii) between the produced $\mathrm{CH}_{3} \mathrm{SO}_{3} \mathrm{H}$ (and later proton) and imidazole near the anode-electrolyte interface. ${ }^{9}$

As a result, protons are transferred from the WE (anode) to the CE (cathode). Simultaneously, imidazole molecules produced at the CE are thus "transported" reversely from the $\mathrm{CE}$ (cathode) to the WE (anode). In line with the analysis of cyclic voltammograms recorded in $\mathrm{N}_{2} v s$. in $\mathrm{H}_{2}$ of Pt electrode immersed in imidazolium bis(trifluoromethanesulfonyl)imide, ${ }^{63,64}$ the following processes are proposed to occur dominantly in the electrochemical cell:

$$
\text { Anode (WE): } \mathrm{H}_{2}+2 \mathrm{C}_{3} \mathrm{H}_{4} \mathrm{~N}_{2} \rightarrow 2 \mathrm{C}_{3} \mathrm{H}_{5} \mathrm{~N}_{2}^{+}+2 \mathrm{e}^{-}
$$

Electrolyte: $\mathrm{H}^{+}$conducts from the anode to the cathode

$$
\text { Cathode (CE): } 2 \mathrm{C}_{3} \mathrm{H}_{5} \mathrm{~N}_{2}^{+}+2 \mathrm{e}^{-} \rightarrow 2 \mathrm{C}_{3} \mathrm{H}_{4} \mathrm{~N}_{2}+\mathrm{H}_{2}
$$

Fig. $4 \mathrm{~b}$ shows the cyclic voltammograms recorded at $20 \mathrm{mV}$ $\mathrm{s}^{-1}$ under dry $\mathrm{H}_{2}, \mathrm{~N}_{2}$ and $\mathrm{O}_{2}$ atmosphere, respectively. These cyclic voltammograms were stable and resemble the corresponding cyclic voltammograms of $\mathrm{Pt}$ in imidazolium bis(trifluoromethanesulfonyl)imide. ${ }^{63,64}$ When the WE is in a $\mathrm{N}_{2}$<smiles></smiles>

(i)

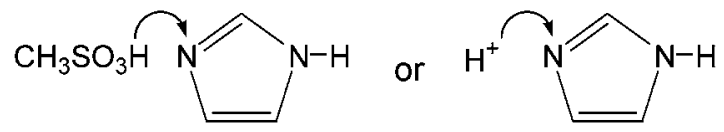

(ii)

Scheme 1 Schematic of possible proton conduction via a fast proton hopping mechanism when the WE is in a $\mathrm{H}_{2}$ atmosphere: (i) near the cathode-electrolyte interface and in the electrolyte bulk and (ii) near the anode-electrolyte interface. 
atmosphere, the cyclic voltammogram is also similar to that for the blend of $1 \mathrm{H}-1,2,4$-triazole and $\mathbf{1},{ }^{\mathbf{4 0}}$ confirming that the potential of $0 \mathrm{~V}$ corresponds to the hydrogen redox potential in 1 and therefore the RE can be considered as a RHE. ${ }^{40,63,64}$

When $\mathrm{H}_{2}$ gas is bubbled into 1 around the WE, a notable and steady oxidation current corresponding to the HOR was observed. Similar to the dominant process in the chronoamperometric analysis, the likely anodic and cathodic reactions are as follows:

$$
\begin{aligned}
& \text { Anode (WE): } \mathrm{H}_{2}+2 \mathrm{C}_{3} \mathrm{H}_{4} \mathrm{~N}_{2} \rightarrow 2 \mathrm{C}_{3} \mathrm{H}_{5} \mathrm{~N}_{2}^{+}+2 \mathrm{e}^{-} \\
& \text {Cathode (CE): } 2 \mathrm{C}_{3} \mathrm{H}_{5} \mathrm{~N}_{2}^{+}+2 \mathrm{e}^{-} \rightarrow 2 \mathrm{C}_{3} \mathrm{H}_{4} \mathrm{~N}_{2}+\mathrm{H}_{2}
\end{aligned}
$$

In fact, while imidazole molecules are proposed to be generated at the $\mathrm{CE}$, the evolution of $\mathrm{H}_{2}$ gas at the $\mathrm{CE}$ was visually confirmed. Thus, in terms of interfacial electrochemical properties, it is likely that different from the bulk properties for which the vehicle mechanism was proposed for ionic conduction of $1,{ }^{40}$ proton conduction from the WE to the CE may occur via a proton exchange reaction between $\mathrm{C}_{3} \mathrm{H}_{5} \mathrm{~N}_{2}{ }^{+}$and the generated $\mathrm{C}_{3} \mathrm{H}_{4} \mathrm{~N}_{2}$ as depicted in Scheme 1.,37,63

Upon switching to an $\mathrm{O}_{2}$ atmosphere for the WE, a significant change in the shape of the voltammogram was observed. A cathodic current was observed at a potential below $+0.75 \mathrm{~V} v s$. RHE, indicating oxygen reduction reaction (ORR). In accordance with the previous finding, ${ }^{\mathbf{4 0 , 6 3 , 6 4}}$ the imidazolium cation (protonated imidazole) was also found to be active for the ORR at Pt immersed in 1, although the overpotential of the ORR was rather large. Similarly, the reaction might be:

$$
\mathrm{O}_{2}+4 \mathrm{C}_{3} \mathrm{H}_{5} \mathrm{~N}_{2}^{+}+4 \mathrm{e}^{-} \rightarrow 4 \mathrm{C}_{3} \mathrm{H}_{4} \mathrm{~N}_{2}+2 \mathrm{H}_{2} \mathrm{O}
$$

Fig. 4c displays the linear sweep voltammogram scanned at $10 \mathrm{mV} \mathrm{s}^{-1}$ for 1 with the WE under a $\mathrm{N}_{2}$ atmosphere. The electrochemical window (EW), obtained as the potential range where the reduction and oxidation current densities both remain within $1.0 \mathrm{~mA} \mathrm{~cm}^{-2}$, was $2.0 \mathrm{~V}$ for 1 . The high electrochemical stability validates the possibility of the application of $\mathbf{1}$ as electrolyte for high temperature PEMFCs under nonhumidifying conditions.

\subsection{Characterizations of the membranes}

Membrane characterizations were carried out to evaluate the possible applications of $\mathbf{1}$ in the state-of-the-art Nafion membranes. As shown in Fig. 5, the comparison among the FTIR spectra of pristine Nafion 212 membrane, composite Nafion 212 membrane, $\mathbf{1}$ and imidazole demonstrates that $\mathbf{1}$ has been successfully doped into the composite Nafion membrane matrix while the imidazole component as a solvent has been completely eliminated from the membrane.

The conventional powder XRD measurements $(\theta-2 \theta$ scan $)$ (Fig. 6) also confirm the significant doping of 1 in the Nafion membrane as the composite membrane exhibits particularly a

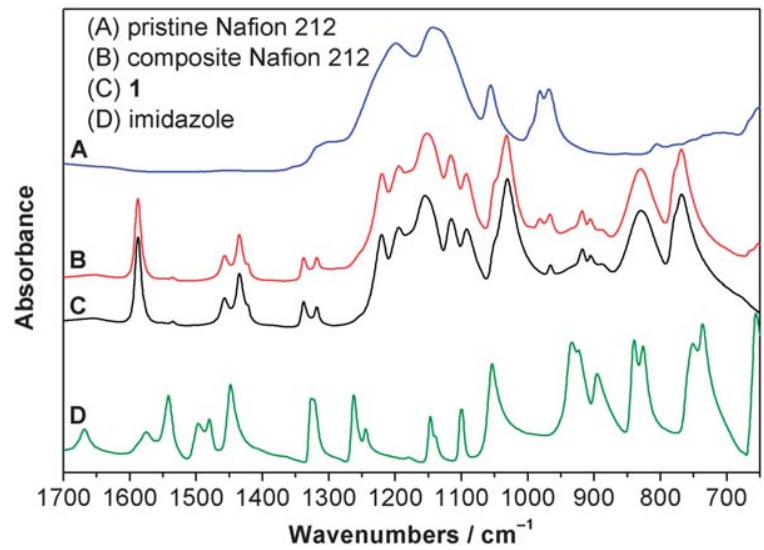

Fig. 5 FT-IR spectra of pristine Nafion 212 membrane, composite Nafion 212 membrane, $\mathbf{1}$ and imidazole at room temperature. The FT-IR spectrum of $\mathbf{1}$ was cited from ref. 40 .

distinct and large diffraction peak corresponding to the two main diffraction peaks of 1 at around $2 \theta=22^{\circ}$.

Furthermore, GIXRD patterns recorded with incident angle $(\omega)$ of $0.5^{\circ}$ reflect clearly the contribution of $\mathbf{1}$ to the crystallinity of the composite membrane surface, as depicted in Fig. 7. The existence of crystalline $\mathbf{1}$ in the deeper layers of the composite membrane is still evident as $\omega$ increases and simultaneously the $\mathrm{X}$-rays penetrate deeper into the membrane (Fig. S4). $\neq$ In addition, TGA trace presented in Fig. 8 shows that the composite membrane is thermally as stable as the pristine membrane in the relevant temperature range $\left(100-200{ }^{\circ} \mathrm{C}\right)$ for high temperature PEMFCs. Further work on 1 and other protic OIPCs with wider temperature ranges of plastic phases and better electrochemical activity as proton conductors for PEMFCs are in progress in our labs. On the other hand, even for anhydrous high temperature PEMFCs, protic OIPC-based membranes may still be challenged by the progressive release of the protic OIPC component due to the water generated during the fuel cell operation. ${ }^{65}$ Luckily, hydrophobic PILs or protic OIPCs with excellent properties (e.g. ethylmethylpropylammonium

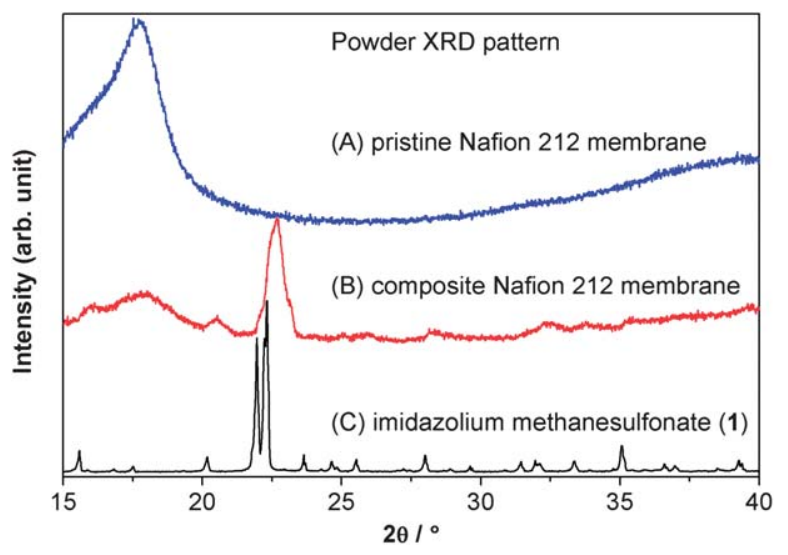

Fig. 6 Powder XRD patterns ( $\theta-2 \theta$ scan) of pristine Nafion 212 membrane, composite Nafion 212 membrane and $\mathbf{1}$ at room temperature. The powder XRD pattern of $\mathbf{1}$ was cited from ref. 40. 


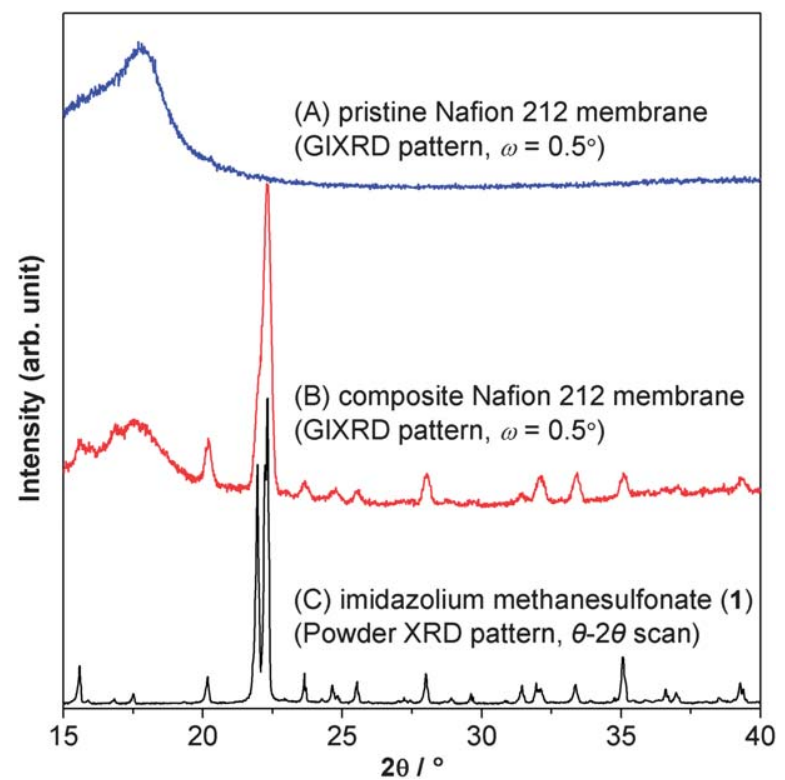

Fig. 7 GIXRD patterns of pristine Nafion 212 membrane and composite Nafion 212 membrane at room temperature with $\omega=0.5^{\circ}$. The powder XRD pattern of 1, cited from ref. 40, was added for comparison.

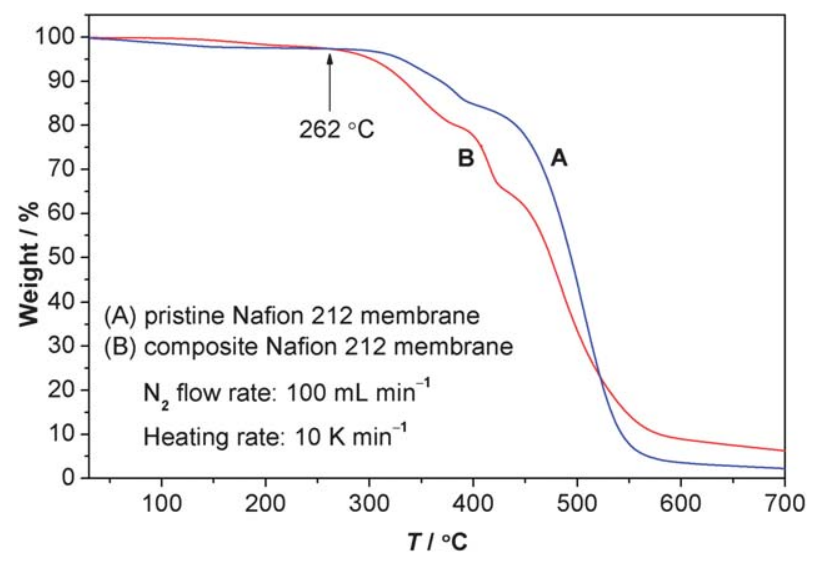

Fig. 8 TGA trace of pristine Nafion 212 membrane and composite Nafion 212 membrane in a $\mathrm{N}_{2}$ atmosphere heated at $10 \mathrm{~K} \mathrm{~min}^{-1}$.

nonafluorobutanesulfonate ${ }^{67}$ ), which have been initially explored by only a few research groups recently, ${ }^{66-71}$ may provide a promising solution for the development of anhydrous proton conductors resistant to leaching for high temperature PEMFCs.

\section{Conclusions}

As a model proton conductor, imidazolium methanesulfonate (1) exhibits crystal (phase II), plastic crystal (phase I) and melt phases successively from ambient temperature to $200{ }^{\circ} \mathrm{C}$. TGA shows the high thermal stability of $\mathbf{1}$. DSC measurement and temperature-dependent XRD together initially reveal the solidsolid phase transition of 1 at $174{ }^{\circ} \mathrm{C}$ shortly before the melting point at $188{ }^{\circ} \mathrm{C}$. The plastic phase ranging from 174 to $188{ }^{\circ} \mathrm{C}$ has also been verified. Particularly, a liquid-like ionic conductivity of $1.0 \times 10^{-2} \mathrm{~S} \mathrm{~cm}^{-1}$ is reached at $185{ }^{\circ} \mathrm{C}$. The activation energy for ionic conduction decreases from the low temperature crystal phase to the high temperature melt phase. It is proposed that proton transport in $\mathbf{1}$ may be described by a Grotthuss mechanism (structural diffusion) in the crystal phase while a vehicle mechanism may contribute to the proton conduction in the plastic phase and dominate the proton conduction in the molten state, leading to the high ionic conductivity as observed. The contribution of protons to the ionic conductivity of $\mathbf{1}$ as a melt was demonstrated via chronoamperometry. In addition, 1 shows electrochemical activities for $\mathrm{H}_{2}$ oxidation and $\mathrm{O}_{2}$ reduction at a Pt electrode as well as adequate electrochemical stability for PEMFC applications. Furthermore, doping of $\mathbf{1}$ into the Nafion matrix has been achieved as identified by FT-IR spectroscopy, powder XRD $(\theta-2 \theta$ scan) and GIXRD. TGA shows that the 1-doped Nafion membrane is thermally as stable as the pristine Nafion membrane in the relevant temperature range $\left(100-200{ }^{\circ} \mathrm{C}\right)$ for high temperature PEMFCs.

\section{Acknowledgements}

The authors would like to thank Dr Martin Knipper and Ms Katja Rieß (University of Oldenburg) for their assistance with powder XRD measurements and TGA/DTA test, respectively. J.L. and I.F.J.V. acknowledge IOF-KP 10/005 of KU Leuven for financial support. J.L. deeply thanks Prof. Dr Carsten Agert and Dr Alexander Dyck (NEXT ENERGY) for their financial support and the opportunity to conduct the experimental work at NEXT ENERGY. J. Luo acknowledges Research Fund KU Leuven for postdoctoral fellowship (PDM-short term). We are grateful to Prof. Dr Koen Binnemans (KU Leuven) and Prof. Dr Philippe Vereecken (IMEC) for technical discussions.

\section{Notes and references}

1 K. Binnemans, Chem. Rev., 2005, 105, 4148.

2 J. M. Pringle, P. C. Howlett, D. R. MacFarlane and M. Forsyth, J. Mater. Chem., 2010, 20, 2056.

3 K. R. Seddon, Nat. Mater., 2003, 2, 363.

4 T. L. Greaves and C. J. Drummond, Chem. Rev., 2008, 108, 206.

5 M. Armand, F. Endres, D. R. MacFarlane, H. Ohno and B. Scrosati, Nat. Mater., 2009, 8, 621.

6 M. Yoshizawa, W. Xu and C. A. Angell, J. Am. Chem. Soc., 2003, 125, 15411.

7 J. Timmermans, J. Phys. Chem. Solids, 1961, 18, 1.

8 V. Armel, D. Velayutham, J. Sun, P. C. Howlett, M. Forsyth, D. R. MacFarlane and J. M. Pringle, J. Mater. Chem., 2011, 21, 7640.

9 S.-Y. Lee, A. Ogawa, M. Kanno, H. Nakamoto, T. Yasuda and M. Watanabe, J. Am. Chem. Soc., 2010, 132, 9764.

10 L. Wang, S. G. Advani and A. K. Prasad, Electrochem. SolidState Lett., 2012, 15, B44.

11 T. Yasuda, S.-i. Nakamura, Y. Honda, K. Kinugawa, S.-Y. Lee and M. Watanabe, ACS Appl. Mater. Interfaces, 2012, 4, 1783. 
12 F. Yan, S. Yu, X. Zhang, L. Qiu, F. Chu, J. You and J. Lu, Chem. Mater., 2009, 21, 1480.

13 A. Fernicola, S. Panero and B. Scrosati, J. Power Sources, 2008, 178, 591.

14 Q. Tang, J. Wu, Z. Tang, Y. Li and J. Lin, J. Mater. Chem., 2012, 22, 15836.

15 J. Luo, O. Conrad and I. F. J. Vankelecom, J. Mater. Chem., 2012, 22, 20574.

16 U. A. Rana, R. Vijayaraghavan, M. Walther, J. Sun, A. A. J. Torriero, M. Forsyth and D. R. MacFarlane, Chem. Commun., 2011, 47, 11612.

17 J.-P. Belieres, D. Gervasio and C. A. Angell, Chem. Commun., 2006, 4799.

18 A. K. Mishra, T. Kuila, D.-Y. Kim, N. H. Kim and J. H. Lee, J. Mater. Chem., 2012, 22, 24366.

19 A. Fernicola, S. Panero, B. Scrosati, M. Tamada and H. Ohno, ChemPhysChem, 2007, 8, 1103.

20 M. Moriya, T. Watanabe, W. Sakamoto and T. Yogo, RSC Adv., 2012, 2, 8502.

21 D. R. MacFarlane, J. Huang and M. Forsyth, Nature, 1999, 402, 792.

22 Q. Li, J. Zhao, B. Sun, B. Lin, L. Qiu, Y. Zhang, X. Chen, J. Lu and F. Yan, Adv. Mater., 2012, 24, 945.

23 Q. Li, X. Chen, J. Zhao, L. Qiu, Y. Zhang, B. Sun and F. Yan, J. Mater. Chem., 2012, 22, 6674.

24 P. Wang, Q. Dai, S. M. Zakeeruddin, M. Forsyth, D. R. MacFarlane and M. Gratzel, J. Am. Chem. Soc., 2004, 126, 13590.

25 S. Horike, D. Umeyama, M. Inukai, T. Itakura and S. Kitagawa, J. Am. Chem. Soc., 2012, 134, 7612.

26 Y. Abu-Lebdeh, A. Abouimrane, P.-J. Alarco, I. Dividson and M. Armand, J. Power Sources, 2006, 159, 891.

27 S. Long, P. C. Howlett, D. R. MacFarlane and M. Forsyth, Solid State Ionics, 2006, 177, 647.

28 Y. Abu-Lebdeh, A. Abouimrane, P.-J. Alarco, A. Hammami, L. Ionescu-Vasii and M. Armand, Electrochem. Commun., $2004,6,432$.

29 U. A. Rana, R. Vijayaraghavan, D. R. MacFarlane and M. Forsyth, Chem. Commun., 2011, 47, 6401.

30 M. Yoshizawa-Fujita, K. Fujita, M. Forsyth and D. R. MacFarlane, Electrochem. Commun., 2007, 9, 1202.

31 U. A. Rana, R. Vijayaraghavan, D. R. MacFarlane and M. Forsyth, J. Mater. Chem., 2012, 22, 2965.

32 M. Hattori, S. Fukada, D. Nakamura and R. Ikeda, J. Chem. Soc., Faraday Trans., 1990, 86, 3777.

33 S. Iwai, M. Hattori, D. Nakamura and R. Ikeda, J. Chem. Soc., Faraday Trans., 1993, 89, 827.

34 H. Suga, M. Sugisaki and S. Seki, Mol. Cryst., 1966, 1, 377.

35 K. Kuchitsu, H. Ono, S. i. Ishimaru, R. Ikeda and H. Ishida, Phys. Chem. Chem. Phys., 2000, 2, 3883.

36 W. L. F. Armarego and C. L. L. Chai, Purification of Laboratory Chemicals, Butterworth-Heinemann, Oxford, 6th edn, 2009.

37 K. D. Kreuer, A. Fuchs, M. Ise, M. Spaeth and J. Maier, Electrochim. Acta, 1998, 43, 1281.

38 (a) U. Thanganathan, J. Mater. Chem., 2012, 22, 9684; (b) J. Sun, L. R. Jordan, M. Forsyth and D. R. MacFarlane,
Electrochim. Acta, 2001, 46, 1703; (c) C. Yang, P. Costamagna, S. Srinivasan, J. Benziger and A. B. Bocarsly, J. Power Sources, 2001, 103, 1; (d) H. Chen, T. Yan and G. A. Voth, J. Phys. Chem. A, 2009, 113, 4507; (e) S. Bureekaew, S. Horike, M. Higuchi, M. Mizuno, T. Kawamura, D. Tanaka, N. Yanai and S. Kitagawa, Nat. Mater., 2009, 8, 831.

39 A. K. Covington and R. Thompson, J. Solution Chem., 1974, 3, 603.

40 J. Luo, T. V. Tan, O. Conrad and I. F. J. Vankelecom, Phys. Chem. Chem. Phys., 2012, 14, 11441.

41 J. Luo, J. Hu, W. Saak, R. Beckhaus, G. Wittstock, I. F. J. Vankelecom, C. Agert and O. Conrad, J. Mater. Chem., 2011, 21, 10426.

42 J. M. Chezeau and J. H. Strange, Phys. Rep., 1979, 53, 1.

43 G. R. Goward, K. Saalwächter, I. Fischbach and H. W. Spiess, Solid State Nucl. Magn. Reson., 2003, 24, 150.

44 E. Chang, Y. Fu and J. Kerr, US DOE J. Undergrad. Res., 2009, 9, 40 .

45 J. W. Traer and G. R. Goward, Phys. Chem. Chem. Phys., 2010, 12, 263.

46 W. Münch, K.-D. Kreuer, W. Silvestri, J. Maier and G. Seifert, Solid State Ionics, 2001, 145, 437.

47 J. W. Traer, J. F. Britten and G. R. Goward, J. Phys. Chem. B, 2007, 111, 5602.

48 D. R. MacFarlane, P. Meakin, N. Amini and M. Forsyth, J. Phys.: Condens. Matter, 2001, 13, 8257.

49 Y. Abu-Lebdeh, P.-J. Alarco and M. Armand, Angew. Chem., Int. Ed., 2003, 42, 4499.

50 M. Lee, U. H. Choi, S. Wi, C. Slebodnick, R. H. Colby and H. W. Gibson, J. Mater. Chem., 2011, 21, 12280.

51 R. Asayama, J. Kawamura and T. Hattori, Chem. Phys. Lett., $2005,414,87$.

52 W. A. Henderson, V. G. Young, Jr., W. Pearson, S. Passerini, H. C. De Long and P. C. Trulove, J. Phys.: Condens. Matter, 2006, 18, 10377.

53 T. Enomoto, S. Kanematsu, K. Tsunashima, K. Matsumoto and R. Hagiwara, Phys. Chem. Chem. Phys., 2011, 13, 12536.

54 J. M. Pringle, J. Adebahr, D. R. MacFarlane and M. Forsyth, Phys. Chem. Chem. Phys., 2010, 12, 7234.

55 T. Shimizu, S. Tanaka, N. Onoda-Yamamuro, S. Ishimaru and R. Ikeda, J. Chem. Soc., Faraday Trans., 1997, 93, 321.

56 L. Jin, K. M. Nairn, C. M. Forsyth, A. J. Seeber, D. R. MacFarlane, P. C. Howlett, M. Forsyth and J. M. Pringle, J. Am. Chem. Soc., 2012, 134, 9688.

57 K.-D. Kreuer, A. Rabenau and W. Weppner, Angew. Chem., Int. Ed. Engl., 1982, 21, 208.

58 M. F. H. Schuster, W. H. Meyer, M. Schuster and K. D. Kreuer, Chem. Mater., 2004, 16, 329.

59 R. M. Lynden-Bell, A. I. Frolov and M. V. Fedorov, Phys. Chem. Chem. Phys., 2012, 14, 2693.

60 F. Endres, N. Borisenko, S. Z. E. Abedin, R. Hayes and R. Atkin, Faraday Discuss., 2012, 154, 221.

61 M. Z. Bazant, B. D. Storey and A. A. Kornyshev, Phys. Rev. Lett., 2011, 106, 046102. 
62 X. Si, S. Li, Y. Wang, S. Ye and T. Yan, ChemPhysChem, 2012, 13, 1671.

63 A. Noda, M. A. B. H. Susan, K. Kudo, S. Mitsushima, K. Hayamizu and M. Watanabe, J. Phys. Chem. B, 2003, 107, 4024.

64 M. A. B. H. Susan, A. Noda, S. Mitsushima and M. Watanabe, Chem. Commun., 2003, 938.

65 B. Lin, S. Cheng, L. Qiu, F. Yan, S. Shang and J. Lu, Chem. Mater., 2010, 22, 1807.

66 J.-F. Huang, H. Luo, C. Liang, I.-W. Sun, G. A. Baker and S. Dai, J. Am. Chem. Soc., 2005, 127, 12784.
67 T. Yasuda, A. Ogawa, M. Kanno, K. Mori, K. Sakakibara and M. Watanabe, Chem. Lett., 2009, 38, 692.

68 H. Luo, G. A. Baker, J. S. Lee, R. M. Pagni and S. Dai, J. Phys. Chem. B, 2009, 113, 4181.

69 M. S. Miran, H. Kinoshita, T. Yasuda, M. A. B. H. Susan and M. Watanabe, Phys. Chem. Chem. Phys., 2012, 14, 5178.

70 J. Snyder, T. Fujita, M. W. Chen and J. Erlebacher, Nat. Mater., 2010, 9, 904.

71 Y. Tan, C. Xu, G. Chen, N. Zheng and Q. Xie, Energy Environ. Sci., 2012, 5, 6923. 